\title{
CORRELATION BETWEEN LECTURER PROFESSIONALISM AND SELF-EFFICACY IN COLLEGE STUDENTS
}

\author{
Frieda N. R. Hidayati; Siswati \\ Faculty of Psychology, Diponegoro University, Semarang, Indonesia \\ Email: frieda.nrh@gmail.com
}

\begin{abstract}
The development process of self-efficacy in college students are influenced by several factors namely family influence, peer influence, the influence of school environment (including the characteristics of educators), the transitional situation at school, and self-appraisal skills. Lecturers play important roles for the college students in the process of teaching and learning. To increase the quality of the teaching-learning process in colleges, lecturers are required to enhance their professionalism. The research was aimed to assess the correlation between self-efficacy in college students and college student perception on lecturer professionalism. The research was conducted by college students, batch 2016/2017, Faculty of Psychology, Diponegoro University. There were 175 students distributed in four classes. All classes were selected as the research subjects. Data were obtained using two scales namely EDA (Efikasi Diri Akademik/Academic Self-efficacy) Scale and PTPD (Persepsi Terhadap Profesionalisme Dosen/Perception on Lecturer Professionalism) Scale and were then analyzed using simple regression statistics by means of SPSS Software. The result of the research shows the correlation between self-efficacy in college students and college student perception on lecturer professionalism with the value of $r=0.271$ with $p=0.000(p<.01)$. The research also indicates that lecturer professionalism contributes $7.3 \%$ to self-efficacy in college students. It leads to the conclusion that the dominating factor which influences self-efficacy in college students is not lecturer professionalism. Following factors like self-appraisal, peer influence, and family influence might have greater influence, yet further research is needed.
\end{abstract}

Keywords: academic self-efficacy, lecturer professionalism, college students.

\section{INTRODUCTION}

The first year in the university is the transitional period which has to be passed by high school students who decided to continue their study. The program to introduce freshmen to higher education has not provided a warranty that the freshmen will be able to adapt and survive to pass the study period within the specified time and graduate with maximum Grade Point Average (GPA). Different academic requirements compared to what they had at high school make some students feel unsure that they can complete their study on time.

Besides cognitive and adaptive skills, studying in university requires the ability to determine the actions to be taken and how much effort and how long a person will be able to withstand the situation. In other words, high self-efficacy is needed. Self-efficacy is defined as one's belief in his/her ability to accomplish a task related to situations faced by the individual (Bandura, 1997). Self-efficacy in college students, also known as academic self-efficacy, supports college students' believe to manage and perform a series of actions needed to achieve certain performance. College students having good academic self-efficacy will be able to manage their activity, effort, and strength to face challenges, because they have the endurance to solve difficult problems, do not give up easily, and show effective actions. Related to the process of the development of academic self-efficacy, Schunk and Pajares (2000) stated that the influencing factors are the family influence, peer influence, influence of school environment (including the characteristics of educators), transitional situation at school, and self-appraisal skills.

For college students, the presence of lecturers is the most important component in the teaching-learning process. One of the main aspects determining the quality of the educational institution is the teaching-learning-process (Tadjudin, 2002). Related to the previous statement, the policy of the Ministry of National Education of the Republic of Indonesia for higher education programs focuses on improving the quality of teaching-learning process (Depdiknas, 2003). To improve the quality of learning process in higher education, lecturer professionalism is a considerable aspect. There are four competencies 
which should be possessed by lecturers related to their main duty as a teacher as well as an educator. Those competencies are the competence of understanding the learners, the competence of educational learning, and the competence of personality and professional development.

Whether there is a correlation between academic self-efficacy in college students and college students' perception of lecturer professionalism was the research question of the study. The research was aimed to assess the correlation between academic self-efficacy in college students and college students' perception of lecturer professionalism.

\section{Self-efficacy and Academic Self-efficacy}

Through his theory of social learning cognition, Bandura stated the concept of self-efficacy first time in 1981. The concept stated that selfefficacy correlates to the individual belief that he/she applies personal controls on motivation, cognitive behavior, affection, and social environment. The essential element of self-efficacy is its influence on feelings, thoughts, and one's actions. Watson (1986) stated that self-efficacy is one's ability to make the decision on a situation. Bandura (1986) mentioned that self-efficacy refers to perceptions of individual abilities to perform certain skills. Schwarzer (1992) referred to Bandura stated that an individual having good self-efficacy will survive longer to solve difficult problems compared to those with low selfefficacy. An individual with low self-efficacy will get discouraged easily when facing problems and stop finding more effective actions. The statement indicates that self-efficacy is an important factor in performing self-control and control to the environment. Schultz (1994) who continued Bandura's point of view defined self-efficacy as the feelings on adequacy, efficiency and ability to cope with life. According to Baron \& Byrne (2000), self-efficacy is an individual assessment on the ability to perform actions to achieve the objective and generating outcomes. If those statements are connected to academic activities, academic self-efficacy can be defined as one's believe in his/her abilities to control themselves and surroundings to accomplish their learning objectives and generating academic achievements.
Self-efficacy has become the basis for individuals to do extra efforts, even when they face challenges. In general, according to Bandura (1997) self-efficacy can be seen from three-dimensional points of view, namely: a. Level of difficulties of assignments so that special competence is needed; $b$. The scope of the assignment, and c. Individual believes that he/she will be able to accomplish the assignment with the expected result. The sources or factors of self-efficacy are a. Personal experiences on success or failure (success will increase self-efficacy while failure will reduce self-efficacy), b. Others' experiences, c. Verbal persuasion from others on individual skills, and d. A physiological condition that controls individual emotional situations like fatigue, anxiety, and stress (Blyth et.al, 2002).

Academic self-efficacy has been a topic for research. Some of the research on academic selfefficacy was conducted by Schunk (1995), Pajares (1996) and Bandura (1997) which shows that academic self-efficacy is closely related to achievement. In 1990, Pintrich and De Groot provided evidence that academic self-efficacy is related to self-regulation and cognitive strategy. In 1991, Bouffard-Bouchard, Parent, and Larivee obtained a result that students having good academic self-efficacy develop an ability to maintain their performance and being more directional than students who have low self-efficacy. In 2009, Iskender (2009) conducted a research to observe the gender influence of self-efficacy which results in a finding that gender has no correlation with self-efficacy. Similar research was also conducted by Schunk, Pajares, and Bandura, then also conducted by Sharma and Nasa which emphasizes that academic self-efficacy is the reliable predictor of educational performance. A research conducted by Akin and Akin (2015) results in a conclusion that self-compassion contributes $58 \%$ to self-efficacy in college students.

\section{Lecturer Professionalism Lecturer as the component of teaching- learning process}

In 2015, the Ministry of Research, Technology, and Higher Education of the Republic of Indonesia conducted a mapping of the teachinglearning process by visiting several universities in Indonesia. The activity was aimed to develop 
an instrument to measure the quality of the teaching-learning process in universities in Indonesia. This is important since the teaching-learning process has played a role as the core of university or higher education. The importance of teachinglearning process is reflected from the strategic objectives of the Ministry of Research, Technology, and Higher Education of the Republic of Indonesia stating the first strategy as the focus on the quality of learning. There are 5 (five) Strategic Objectives that need to be accomplished within the 2015-2019 period. Those are 1. Improvement of higher education learning process and student quality; 2. Improvement on Science $\&$ Technology Institutions and higher education quality; 3. Improvement on relevancy, quality, and quantity of human resource for higher education and science and technology; 4. Improvement on relevancy and productivity of research and development; and 5. Strengthen innovation capability (LP2M UNNES, 2015).

The research on the importance of lecturer's presence was conducted by Kamarudin and Ibrahim (2010). The research was aimed to determine required competence of a lecturer and resulted in a conclusion that a lecturer should possess professional competence (including specific knowledge and knowledge and skills on effective teaching) and general competence (including general knowledge and specific knowledge and skills in another field such as science, mathematics, language, and psychology).

\section{Lecturer Professionalism}

"Profession" comes from the word profession or Latin professor and professionally comes from the word professional. One of the definitions of profession, as mentioned by Page and Thomas (in Amir, 2010), is described as a very prestigious work and can be called professional when it is generating benefits for social services, which can be done with systematic knowledge gained from long-term academic education and training, has a high autonomy and code of ethics. A profession is usually associated with a professional code of ethics, professional associations, certification process and a special license for the profession. "Professional" means a person whoholds a position or job which is done with high skill carefully and according to the science and education, he/ she takes. "Professionalism" is a commitment of members of the profession to improve its ability continuously. "Professionalization" is the process or time travel that makes a person or group of people becomes professional.

Lecturer professionalism has a specialty that is discussed in the research. Relative scientific truth is a rewarding achievement. Lecturer professionalism plays a major role in improving the quality of the learning process in university. Lecturer professionalism is expected to have high performance that can satisfy all related party (stakeholders), i.e. college students, parents and society in a broad sense. Besides to satisfy stakeholders, this high performance also satisfies the individual. For a professional, spiritual satisfaction is the ultimate compensation expected of a job. As a professional, lecturers are required to have a number of competencies in order to perform their duties properly and called professional. Because both teachers and lecturers are essentially carrying out the same tasks, teacher competence profiles can be applied to lecturers. This competence consists of four fields, namely the competence of the field of study, the competence of understanding the learners, the competence of educational learning, and the competence of personality and professional development. The four competencies can be said as a component or aspect of lecturer professionalism. Explanation of each competency is as follows: (1) The competence of the field of study includes two things, namely the mastery of the discipline and the mastery of curricula. The mastery of the discipline is concerned with the substance and methodology of knowledge. The curricular mastery deals with the selection, arrangement, packaging, and representation of materials that meet the needs of learners. (2) The competence of understanding the learners is necessary for providing educational services oriented to learners. As an educator, lecturers must understand the student's initial and the final targeted conditions. The student's condition meant here can be knowledge and skill. To know these two conditions, lecturers are required to have mastery of the principles of measurement and evaluation (evaluation competence). In addition, lecturers must also understand the differences between individuals among the college students. These individual differences include intellectual, emotional, spiritual, social, cultural, 
economic, political, and learning styles. Basically, each student is a unique individual who demands different services. (3) The competence of educational learning is needed so that teachers can manage learning that is educational and oriented to learners. This competence is reflected, both in planning, implementing and evaluating. In designing learning, there are at least four things to note, namely goals, learners, methods and learning activities, and evaluation. (4) The competence of personality and professional development reflects the professional ability of lecturers to be able to identify, measure and develop their capabilities independently. In this case, lecturers are always required to follow the development of science, both with regard to the subject matter or pedagogical content knowledge. As a professional with personality, a lecturer in carrying out his duties is always oriented to the benefit of students. Thus, its orientation towards meets the needs of responsible and human students.

\section{Correlation between academic self-efficacy and college students' perception of lecturer professionalism.}

In the education system, the teaching-learning process is seen as a central variable that contributes directly to the achievement of learning outcomes (product variables).The educational/ learning system consists of four groups of variables, namely presage variables (teachers and students characteristics), context variables (e.g. classroom size, classroom grouping, classroom physical conditions), process variables (teachinglearning situations, teaching-learning interactions, teaching methods), and product variables (skills/ability, achievement of learning outcomes) Process variables are influenced by teachers and students characteristics and context variables. Process variables are directly related to outcome variables.

Associated with the teaching-learning process in university, in order to implement Three Pillars of Higher Education, the university and the lecturers carry out three types of activities, namely education and teaching, research, and community service. As mentioned earlier, the main area of lecturers' activity is to carry out education and teaching. Nevertheless, research activities and community service must also be carried out by a lecturer. Both of these activities will greatly support better education and teaching activities (Directorate of Research and Community Service, 2002). As a professional, lecturers are required to have a number of competencies in order to perform their duties properly. Competencies discussed only relate to the main task of lecturers, namely organizing education and teaching. So, the competence meant here is the competence of lecturers as teachers.

\section{METHOD}

Variables that will be used in this research are:

\author{
Predictor Variable (X) \\ Perception of Lecturer Professionalism \\ Criterion Variable (Y) \\ Academic Self-Efficacy
}

The operational definition of these research variables are as follows:

\section{Academic Self-Efficacy}

It is the individual's faith or belief about his or her ability to be able to control oneself and the environment so as to achieve learning goals and produce academic achievement. Academic selfefficacy will be measured through aspects of task difficulty, task broadness and strength of confidence, using the EDA scale

Perception of Lecturer Professionalism

Is the student's evaluation of lecturer's ability related to the mastery of the field of study, learners' understanding, mastery of educational learning, and the development of personality and professionalism. Perceptions of lecturer professionalism will be measured through the perception aspects of the mastery of the field of study, the perception of learners' understanding, the perception of mastery of learning and the perception of lecturers' personality development using the scale of PTPD.

The population studied was the college students of the Faculty of Psychology Diponegoro University with characteristics: (1) Enrolled as a student in academic year 2016/2017; (2) Graduated from high school by 2016. 
This study used all students of the class of 2016, which spread in four classes as the research subject. Data collection in this study using two psychological scales that are: (1) Academic Self-efficacy Scale (called the EDA scale); (2) Perception Scale on Lecturer Professionalism (called PTPD scale). Data were analyzed by using simple linear regression with SPSS program.

\section{RESULT AND DISCUSSION}

Subjects were 175 people taken from four classes of students in the academic year of 2016. Based on the test results, the number of Perception Scale on Lecturer Professionalism (PTPD) consists of 36 items with 22 valid items $(61 \%)$ and 14 invalid items (39\%). Based on the test results, the number of Academic Self Efficacy Scale (EDA) items consists of 36 items with 25 valid items (75\%) and 11 invalid items (25\%).

Simple linear regression analysis showed a correlation coefficient of 0.271 with $\mathrm{p}=$ $0.000(\mathrm{p}<.01)$. The coefficient which has positive value indicates that the direction of the correlation between the two variables is positive, meaning that the higher (the better) the lecturer professionalism, the higher the student selfefficacy.

The result was a part of academic selfefficacy. Academic self-efficacy has been a topic for research. Some of the research on academic self-efficacy was conducted by Schunk (1995), Pajares (1996) and Bandura (1997) which shows that academic self-efficacy is closely related to achievement. In 1990, Pintrich and De Groot provided evidence that academic self-efficacy is related to self-regulation and cognitive strategy. In 1991, Bouffard-Bouchard, Parent, and Larivee obtained a result that students having good academic self-efficacy develop an ability to maintain their performance and being more directional than students who have low selfefficacy. In 2009, Iskender (2009) conducted a research to observe the gender influence of selfefficacy which results in a finding that gender has no correlation with self-efficacy. Similar research was also conducted by Schunk, Pajares, and Bandura, then also conducted by Sharma and Nasa which emphasizes that academic selfefficacy is the reliable predictor of educational performance. A research conducted by Akin and
Akin (2015) results in a conclusion that selfcompassion contributes $58 \%$ to self-efficacy in college students.

The significance level $\mathrm{p}=0.000(\mathrm{p}<.01)$ indicates a significant correlation between lecturer professionalism and student self-efficacy. Results of simple linear regression analysis showed the hypothesis proposed by the researcher, that the higher the professionalism of the lecturer, the higher the students' academic self-efficacy, is accepted. The value of determination coefficient ( $\mathrm{R}$ square) is equal to 0.073 which means in this research, lecturer professionalism gives an effective contribution of $7.3 \%$ on student academic self-efficacy, while the remaining $92.7 \%$ is determined by other factors which are not revealed in this study.

The teaching-learning process is an interaction between teachers and students which is completed with a process of learning evaluation (Amir, 2010). Another definition was stated by Hamalik (in Amir, 2010) stating that teachinglearning process is a process when teachers and students interact to accomplish learning objectives in a specified location and specified duration of time. The teaching-learning process involves several components such as teachers (educators), students, learning materials, media, and learning evaluation. In traditional teachinglearning process, students are positioned as the objects of learning and educators act as the subjects. Yet, recently, the paradigm has changed. Nowadays, the focus of the process is on students. The new paradigm is based on the understanding that teaching-learning process always involves two active parties i.e. teacher and students.

In the modern era, technologies shuld be used in classroom. Tang \& Austin (2009) suggest that teacher may use combination of technologies and it should be done creatively to improve class activity. Technology can also develop personal capacity and opportunities to enhance their selfefficay (Hall \& Hall, 2010). The other aspect to improve the student-teacher relationship is belong to the type of communication and how they can shared experiences (Hosek \& Thompson, 2009). This kind of communication can increase motivation for learner, but not many teachers in higher education trained in this field (Brewer \& Burgess, 2005). 
The paradigm was then developed into faculty development which in turn became professional development (Amor, 2010). The term "teaching" has also changed into "learning". The educators in higher education, which is known as a lecturer, is the learning component which creates the learning condition. While students, known as college students, is the component who enjoy the learning conditions created by lecturers. The learning condition should have been designed as a purposeful, systematic, and continuous process. The combination of two components establishes an educative interaction by making use of teaching materials as the media. The interaction mentioned before is defined by Sukmadinata (2004) as an interaction between two personalities that is the lecturer's personality as an adult and students' personality as an individual in transition to adulthood.

For college students, the presence of lecturers is one of the important components in teaching and learning process. Learning conditions created by lecturers build educational interactions between two personalities; those are the personality of the lecturer as an adult and a growing college student to maturity. For students who have just entered the university world, it is required to immediately adapt to a different situation with the time when the student is a high school student. The process of self-adjustment requires the ability of academic self-efficacy. Associated specifically with the process of developing academic selfefficacy, the influencing factors are family influences, peer influences, school environment influences (including teacher characteristics) school transition situation, and self-appraisal skills (Butcher et al, 2010). Lecturer competence as a teacher is needed to help students build their self-efficacy (Fives \& Looney, 2009).

\section{CONCLUSION AND SUGGESTION}

This study aims to determine whether there is or isn't the correlation between the two variables. The hypothesis proposed is that there is a correlation between lecturer professionalism and academic self-efficacy of students. The results obtained show that the hypothesis is accepted, ie there is a correlation between lecturer professionalism and academic self-efficacy of students. It illustrates that the professionalism of lecturers which includes the competence $b$ of the field of study, the understanding of learners, the understanding of the learning process and the development of lecturers' personalities influence the self-efficacy of the students.

References related to research on selfefficacy studies and teaching characteristics (teachers or lecturers) are quite common, but specifically examining the effect of lecturers' professionalism on student self-efficacy so far is difficult to find. This study also shows that the effective contribution of lecturer professionalism to self-efficacy is relatively small. It is estimated because other factors, then those coming from lecturers, give more influence to the formation of academic self-efficacy of the student. As already mentioned that factors affecting the formation of self-efficacy are: a. Own experience of success or failure (success will increase self-efficacy and failure will reduce self-efficacy), b. Experience of others, c. Verbal persuasion received from others about individual abilities, and d. Physiological state that controls individual emotional situations such as fatigue, anxiety, and stress.

The existence of lecturers is indeed one important component in the learning process. Learning conditions created by lecturers build educational interactions between two personalities; those are the personality of the lecturer as an adult and a growing college student to maturity. In this case, the professionalism of lecturers is expected to contribute, but not directly develop student self-efficacy.

The lecturers are expected to develop their professionalism through the various learning process, while the students are also expected to develop self-efficacy through various experiences that can be obtained during the study, either through curricular or extra-curricular activities. For other researchers, it is expected to conduct further research on the factors that can develop academic self-efficacy of students who will support their academic achievement, as well as lecturer professionalism which can support the teaching and learning process.

\section{REFERENCES}

Akin, A., Akin, U. 2015. Investigating Predictive Role Self-Compassion on Self-Efficacy, Journal of Education and Instructional 
Studies in The World, 5, 3, 11-19.

Amir, S. 2010. Peningkatan Profesionalisme Dosen. Sukabumi: STAI Syamsul Ulum.

Bandura, A. 1997. Self-Efficacy the Exercise of Control. New York: W. H. Freeman Company

Baron, R.A \& Byrne, D.R. 2000. Social Psychology, $9^{\text {th }}$ Edition. Pearson Education.

Blyth,R.,Ceedy,D.K.,Dennis,G.L.,Moyle,W.,Pra tt,J.,Vries, S.M.D. 2002. Effect of Maternal Confidence on Breastfeeding Duration-An Application of Breastfeeding Self-Efficacy Theory. Birth, 29, 4, 278-284, DOI10.1046/ j.1523536x2002.00202.x.

Brewer, E. W., \& Burgess, D. N. 2005. Professor's Role in Motivating Students to Attend Class.

Butcher, J., Howard, P., Labone, E., Bailey, M., Groundwater Smith, S., McFadden, M. A. R. K. \& Martinez, K. 2003. Teacher Education, Community Service Learning and Student Efficacy for Community Engagement. AsiaPacific Journal of Teacher Education, 31(2), 109-124.

Depdiknas, Biro Hukum dan Organisasi. 2003. Warta Hukum dan Perundang-Undangan, Vol 4, No. 2.

Direktorat Penelitian dan Pengabdian pada Masyarakat. 2002. Kebijakan dan Program Penelitian dan Pengabdian kepada Masyarakat. Jakarta: Departemen Pendidikan Nasional.

Fives, H., \& Looney, L. 2009. College Instructors' Sense of Teaching and Collective Efficacy. International journal of Teaching and Learning in Higher education, 20(2), 182191.

Hall, R., \& Hall, M. 2010. Scoping The Pedagogic Relationship Between Self-Efficacy and Web 2.0 Technologies. Learning, Media and Technology, 35(3), 255-273.

Hosek, A. M., \& Thompson, J. 2009. Communication Privacy Management and College Instruction: Exploring The Rules and
Boundaries That Frame Instructor Private Disclosures. Communication Education, 58(3), 327-349.

Iskender, M. 2009. The Relationship between Self-Compassion, Self-Efficacy and Control Belief About Learning in Turkeys University Student. Social Behaviour and Personality. 37(5), 711-720, DOI 102224/ sbp.2009.375711.

Kamarudin, W.N.W. \& Ibrahim, M.S. 2010. Lecturer Efficacy, Professional and General Competencies of Malaysian Polytechnic Technical Lecturer.

LP2M UNNES. 2015. Rencana Strategis 2015 2019. //http:Ip2m.unnes.ac.id.4 Maret 2017

Pajares, F. 1996. Self-Efficacy Beliefs in Academic Settings. Review of Educational Research, 66, 543.

Schunk dan Pajares. 2000. The Development of Academic Self-Efficacy, Chapter of Development of Achievement Motivation. San Diego Academic Press, Wigfield, A., Eccles, J.(ed)

Sharma, H.L, \& Nasa, G. 2014. Academic SelfEfficacy Reliable Predictor of Educational Performance, British Journal of Education, 2,3,57-64.

Sukmadinata. 2004. Pengembangan Kurikulum, Teori dan Praktek, Bandung: PT Remaja Rosdakarya.

Tadjudin, M.K. 2002. Sistem Penjaminan Mutu Internal Perguruan Tinggi: Aplikasinya di UI. Disampaikan pada Rapat kerja nasional Pimpinan Perguruan Tinggi Seluruh Indonesia, Yogyakarta.

Tang, T. L. P., \& Austin, M. J. 2009. Students' Perceptions of Teaching Technologies, Application of Technologies, and Academic Performance. Computers \& Education, 53(4), 1241-1255.

Watson,D.L. 1986. Social Psychology, Science and Aplication. USA: Scott Foresman and Company. 